\title{
Some Native "Greens" of Saskatchewan
}

By Keith Best and Archie Budd, Swift Current
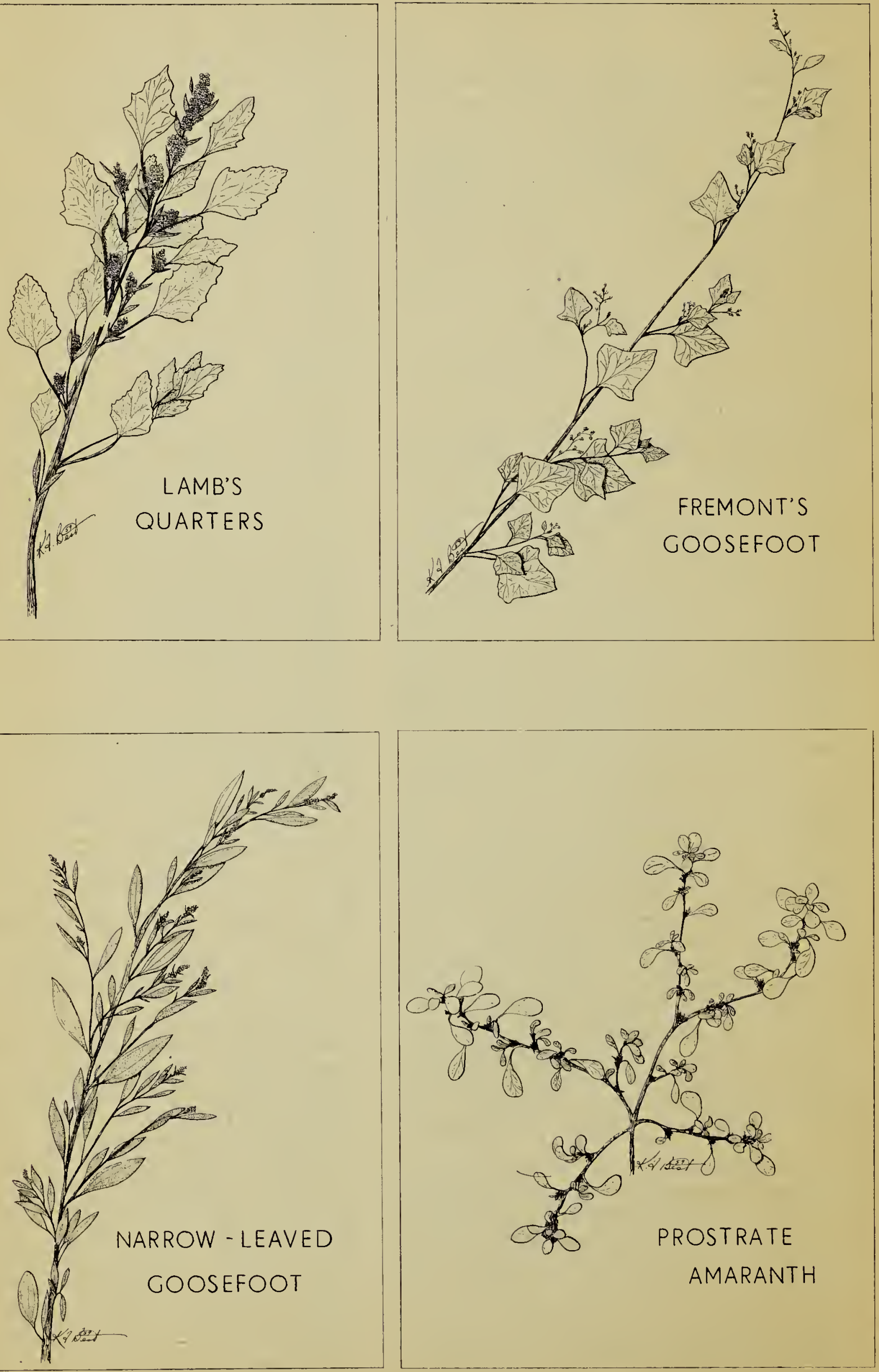
Not only were the fleshy rocits of many plants earten by the Indian and early settlers, but the foliage of many plants was also used. Like us, the early inhabitants realized the value of "greens" in their diet and found many plants to supply this important need. Probably the one that comes mosit readily to mind is Lamb's Quarters, Chenopodium album, which still forms an article of diet for many farm families. The young plants, when boiled, can not be distinguished from spinach and are every bit as good and nourishing. Most of the Chenopodium genus are edible and also tasty. Fremont's Goosefoot, $C$. Fremontii, has smaller and much thinner leaves than Lamb's Quarters and is not nearly as plentiful but thrives in shady locations, under bushes in ravines and along watercourses. Narrow-leaved Goosefoot, $C$. leptophyllum, has narrow leaves, very mealy on the underside and slightly mealy above, and is fairly common in areas of sandy soil in the southwest portion of the province. While somewhat coarser than the previous two species it is nourishing and edible.
The Amaranthaceae or Pigweed family is closely allied to the Goosefoots and two of its members are palatable as greens. These are Tumbleweed, Amaranthus albus, and Prostrate Amaranth, A. graecizans. Tumbleweed is a bushy, whitishstemmed, much branched weed which was found on badger mounds and disturbed places on the prairie. It was the first invader of homestead fireguards and when mature and dry would break off and r.cll in the wind, distributing its many seeds. Prostrate Amaranth was also a plant of the disturbed soil and became a very persistent weed in farm gardens. It is a reddish-stemmed, fleshy plant with dark green, shiny leaves, much darker green than Tumbleweed, and it grows prostrate and spreading on the soil.

Not only were the leaves and stems of these plants cooked but the seeds were also used by the Indians as food, especially those of the Gcosefoots. Practically any plant of the Goosefoot family is edible except perhaps Greasewood and Halogeton, which both contain poisonous properties.

\section{A New Plant Record for Saskatchewan}

\section{By Charles D. Bird, Oklahoma State University, Stillwater}

During the summer of 1957, I worked with the Canadian Wildlife Service carrying out research on my M. Sc. thesis (Vegetational changes as related to waterfowl habitat in artificial lakes of southwestern Saskatchewan, Canada. Oklahoma State Univ., 152 pp., 1958).

On June 20, 1957, I collected Crepis atribarba Heller var. atribarba (965) along the north side of a high hill at the southwest end of Cypress Lake. The plant was associated with $\mathrm{Ga}$ lium boreale L. (962), Comandra pallida A.DC. (963), Senecio canus Hooker (964), Zygadenus gramineus Rydb. (966), Chamaerhodos erecta (L.) Bunge var. nuttallii T. \& G. (967), Campanula rotundifolia L. (968), and Linum lewisii Pursh (969). Identified by Dr. Bernard Boivin, Botany and Plant Pathology Laboratory, Department of Agriculture, Ottawa, the specimen is now in the herbarium of that department.
The species was first described by Heller in 1899 (New and interesting plants from western North AmericaV. Bull. Torr. Bot. Club 26: 312-315) from material collected in 1896, at Lake Waha, Nez Perce County, Idaho. In 1938, Babcock and Stebbins (The American species of Crepis. Carnegie Inst. of Washington Pub. 504, 199 pp.) proposed that the name be changed to Crepis exilis subsp. typica. They recorded the range as "British Columbia to Alberta, south to the Blue Mountains of Oregon, and in the Rockies to Colorado". In their detailed account of distribution, the nearest record to the present one was a specimen collected by Macoun in 1884, from the Cypress Hills, Alberta. According to their records this was the only known collection from AIberta.

The species is not recorded from Saskatchewan in Breitung's recent flora (Amer. Midl. Nat. 58: 1-72. 1957). 